Acta Regionalia et Environmentalica 1

Nitra, Slovaca Universitas Agriculturae Nitriae, 2019, pp. 5-9

\title{
ENTREPRENEURSHIP OF CITIES THROUGH BUSINESS COMPANIES IN THE SLOVAK REPUBLIC
}

\author{
Maroš VALACH*, Peter ÁGH
}

Slovak University of Agriculture in Nitra, Slovak Republic

\begin{abstract}
Local self-governments in the Slovak Republic have many possibilities to do business to capitalize their assets and generate their own budget revenues. The purpose of the article was to identify and evaluate business companies through which local selfgovernments conduct business from different perspectives. We focused on businesses with asset ownership of municipalities with city status. When analyzing businesses, we have taken into account their size, spatial layout, legal form, subject of activity, and their economy. Slovak cities have a long-term experience with conducting business through business companies. Most of these are companies with $100 \%$ ownership of the cities, in terms of the legal form of a limited liability company. The research results confirm that the significant effect of government-run business is the increase in the value of assets.
\end{abstract}

Keywords: local self-government, entrepreneurship, assets of local government

Almost in all developed, but also in developing countries of the world we can meet with some form of public enterprise. Such business has a long tradition in providing certain types of services. According to Arapis (2013) today, the importance of public enterprises is, above all, to build infrastructure, stimulate economic growth, and provide public services and the diversification of revenues of public budgets.

Bel et al. (2010) state that there are five factors that may affect public enterprise, namely:

- management support,

- motivation of employees,

- big expectations,

- the division of labour ("the right person in the right place"),

- and services.

The government, along with the local self-government, plays an important role in promoting entrepreneurship in order to accelerate regional economic growth (Bruton et al., 2015). Garrone et al. (2010) argue that public business plays an important role in relation to the performance of local self-governments.

In drafting the basic legislation that concerns the status of municipalities and cities of Slovakia, when adopting Act No. 369/1990 Coll. on Municipalities, the assets -legal position of the local self-government was clearly defined as follows: "The municipality is a legal entity which, under the conditions established by law, independently manages its own assets and own revenue." Thus, the municipality is a territorial unit in the form of a legal entity, where the law directly assumes that one of its main activities will be the management of its own assets.
Owning assets is the basis for any economic activity of any entity that creates tangible goods or provides services. Therefore, this ownership also applies to municipalities that are required to carry out certain activities under current legislation (Voorn et al., 2017).

Municipalities and cities have a number of opportunities to engage in entrepreneurial activities in the Slovak Republic and thus appreciate their assets (Benčo, 2006). What form of business the municipalities and cities decide for is up to them and this decision is determined by the way of management and controlling the business activities.

The basic legislation governing the local self-government business and the management of public assets in the administration of any municipality is considered as follows:

- Act No. 369/1990 Coll. on Municipalities,

- Act No. 513/1991 Coll. Commercial Code,

- Act No. 595/2003 Coll. on Income Tax,

- Act No. 523/2004 Coll. on the Financial Regulation of General Government.

According to Papcunová and Balážová (2006), municipalities and cities can establish three types of entities for the purpose of doing business:

- Allowance organizations established by a city,

- Businesses with $100 \%$ city ownership,

- Companies with a city ownership of less than $100 \%$.

Hajšová and Kútik (2009) argue that in the beginning of the general establishment a mandatory transformation of municipal enterprises into budget or allowance organizations took place. Budgetary and allowance organizations are established by a resolution of the municipal council, where the municipality issues a founding deed on their establishment. An allowance 
organization is a legal entity that can be set up by a municipality on the basis of basic public functions or intended for public service activities. This organization's budget is made up of revenues, costs, and an economic result. The advantage of this organization is also the possibility of taking a loan.

The municipality can establish a commercial company on the basis of Act No. 513/1991 Coll. Commercial Code. In this Act, a company is defined as a "legal entity established for the purpose of doing business." In terms of the business activities of a municipality, commercial companies are among the most interesting forms of securing those goods and services where profitability is important. By decisions of municipal councils, municipalities may set up commercial companies, mostly joint stock companies or limited liability companies (Tóth et al., 2014).

\section{Material and methods}

The main goal of the paper was to identify and analyze business companies in which local selfgovernments have ownership from various perspectives. We focused on municipalities with a city status in Slovakia; there are 140 of them. Enterprises with ownership of cities were analyzed from the following points of view:

- the number of companies as of December 31, 2018,

- spatial layout

- the level of the city's ownership,

- legal form,

- year of establishment,

- amount of basic capital,

- number of employees,

- field of activity according to SK NACE,

- economic result,

- revenue,

- and asset value.

The economic result, revenues and value of assets were monitored during the period of 2012-2017. The FinStat database was used as the main data source.

\section{Results and discussion}

The use of public assets for business purposes is realized in three basic forms in Slovakia. First and foremost, it is through business companies, secondly, municipalities can also carry out their business activities to a limited extent through their allowance organizations, and in the case of municipalities with lower population, self-businesses are also used, that is doing business in municipality's own name under the Trade Licensing Act. In our research, we have focused on local self-governments making business through business companies.

When monitoring the number of enterprises owned by local selfgovernments for the period of 2005 to 2017, we can say that they significantly reduced (Figure 1). This is a $22.9 \%$ decline over the reporting period.
Currently, from all 140 Slovak cities, only 11 have no ownership in any company, namely: Hanušovce nad Toplou, llava, Leopoldov, Modrý Kameň, Nováky, Rajecké Teplice, Spišská Stará Ves, Strážske, Turany, Vel'ké Kapušany and Zlaté Moravce. Table 1 below provides an overview of the number of companies in which cities have ownership.

Based on the results of the research, we can conclude that there are currently 324 companies with municipal ownership. From the spatial point of view, least municipalities with the status of a city are located in the Bratislava Region (18 trading companies) and vice versa, most of them are in the Banská Bystrica Region (49 trading companies). Although there is the largest number of cities in the Banská Bystrica Region, the largest number of companies with a capital participation does not operate there.

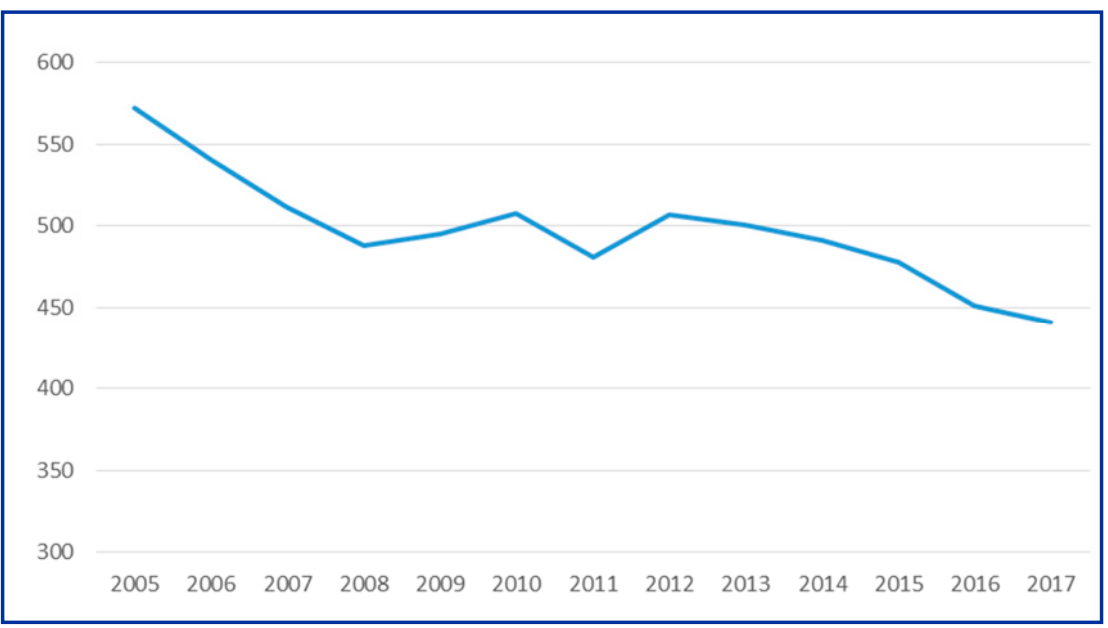

Figure 1 Development of Number of Enterprises Owned by Local Authorities (Municipalities and Cities)

Source: Own processing based on Statistical Yearbooks from 2006 to 2017

Table 1 Number of companies owned by Cities as of December 31, 2018

\begin{tabular}{|l||c|c|}
\hline Region & Number of cities & Number of companies \\
\hline \hline Bratislava Region & 6 & 18 \\
\hline Trnava Region & 18 & 43 \\
\hline Trenčín Region & 18 & 47 \\
\hline Nitra Region & 15 & 27 \\
\hline Žilina Region & 19 & 42 \\
\hline Banská Bystrica Region & 24 & 49 \\
\hline Prešov Region & 23 & 60 \\
\hline Košice Region & 17 & 38 \\
\hline Total & 140 & 324 \\
\hline
\end{tabular}

Source: Own processing of data from finstat.sk 
Table 2 Businesses by the height of share ownership of cities as of December 31, 2018

\begin{tabular}{|l||c|c|}
\hline Business companies owned by local self-governments ownership share & Number & $\%$ \\
\hline Business companies owned by local self-governments - ownership share $\mathbf{1 0 0 \%}$ & 213 & 65.74 \\
\hline Business companies owned by local self-governments - ownership share over $\mathbf{5 0 \%}$ and less than $\mathbf{1 0 0 \%}$ & 34 & 10.49 \\
\hline Business companies owned by local self-governments - ownership share 50\% & 7 & 2.16 \\
\hline Business companies owned by local self-governments - ownership share less than 50\% & 70 & 21.60 \\
\hline Total & 324 & 100.00 \\
\hline
\end{tabular}

Source: Own processing of data from finstat.sk

The region where most of these companies operate is the Prešov Region (60 trading companies).

Of the total number of 324 business companies, there are 213 cases $(65.74 \%)$ of companies with $100 \%$ share ownership of cities (Table 2). In 34 companies (10.49\%), the capital participation of cities is between $50 \%$ and $100 \%$. Seven companies have a $50 \%$ share ownership. The last group are the businesses with a minority share ownership, there is $70(21.6 \%)$ of them.

In terms of legal forms, these are predominantly limited liability companies (93.21\%) and in twenty-two cases (6.79\%) joint stock companies (see Table 3). Other legal forms of companies are not represented, because they are considered not suitable for local self-government. In a public business company, shareholders are liable for their obligations with their entire assets and the murevenuenicipality owns assets that is used for public purposes. As far as the commandite limited partnership is concerned, the municipality can only act as a limited partner, which is liable for its obligations only up to the amount of its outstanding deposit.

Table 4 shows the number of companies with ownership of cities by the period of establishment. Most companies (58.95\%) were established by 2002 . Based on this, we can say that these are long-term companies and that cities have long-term business experience. 110 companies (33.95\%) were established between 2003 and 2012. Since the year

Table 3 Business companies with capital share of cities by legal form as of December 31, 2018

\begin{tabular}{|l||c|c|}
\hline Legal form & Number & $\%$ \\
\hline \hline Limited liability companies & 302 & 93.21 \\
\hline Joint stock companies & 22 & 6.79 \\
\hline Total & 324 & 100.00 \\
\hline
\end{tabular}

Source: Own processing of data from finstat.sk

Table 4

Business companies with capital share of cities by year of establishment as of December 31, 2018

\begin{tabular}{|l||c|c|}
\hline Year of establishment of company & Number & $\%$ \\
\hline \hline Up to 2002 & 191 & 58.95 \\
\hline $\mathbf{2 0 0 3}$ to 2012 & 110 & 33.95 \\
\hline After $\mathbf{2 0 1 3}$ & 23 & 7.10 \\
\hline Total & 324 & 100.00 \\
\hline
\end{tabular}

Source: Own processing of data from finstat.sk
2013, only 23 new companies have been established (7.1\%).

In the following Table 5, companies with equity holdings were divided into three groups by basic capital. The first group includes companies with a basic capital of up to $€ 50,000$; it is the largest group, involving 195 (60.19\%) companies. They are followed by companies with a registered basic capital ranging from $€ 50,000$ to $€ 100,000$, where 17 (5.25\%) of them fall. There are $112(34.57 \%)$ companies with registered basic capital of over $100,000 €$.

When examining companies with capital share of cities, attention was also paid to the assessment of the size structure in terms of the number of employees. Five size groups have been identified (Table 6). Up to 166 (51.23\%) companies have fewer than 10 employees, so in terms of staff we can say that they are so-called micro-enterprises. There are 50 (15.43\%) of the 10 to 19 employees and 68 (20.99\%) of the 20 to 49 employees. Another group, of 50 to 249 employees, which can be described as a group of so-called medium-size enterprises, is made up of $35(10.80 \%)$ companies. There are only 5 (1.54\%) companies with over 250 employees (we call them large enterprises). These companies are: Bratislava

Table $5 \quad$ Business companies with capital share of cities by amount of basic capital as of December 31, 2018

\begin{tabular}{|l||c|c|}
\hline Basic capital of companies & Number & $\%$ \\
\hline \hline Up to $\mathbf{5 0 0 0 0 €}$ & 195 & 60.19 \\
\hline $\mathbf{5 0} \mathbf{0 0 0} \boldsymbol{€}$ to $\mathbf{1 0 0} \mathbf{0 0 0} \boldsymbol{€}$ & 17 & 5.25 \\
\hline Over $\mathbf{1 0 0 0 0 0 €}$ & 112 & 34.57 \\
\hline Total & 324 & 100.00 \\
\hline
\end{tabular}

Source: Own processing of data from finstat.sk

Table 6 Business companies with capital share of cities by number of employees as of December 31, 2018

\begin{tabular}{|l||c|c|}
\hline Number of employees & Number & $\%$ \\
\hline \hline Less than $\mathbf{1 0}$ & 166 & 51.23 \\
\hline $\mathbf{1 0}$ to $\mathbf{1 9}$ & 50 & 15.43 \\
\hline $\mathbf{2 0}$ to $\mathbf{4 9}$ & 68 & 20.99 \\
\hline $\mathbf{5 0}$ to $\mathbf{2 4 9}$ & 35 & 10.80 \\
\hline Over $\mathbf{2 0 5}$ & 5 & 1.54 \\
\hline Total & 324 & 100.00 \\
\hline
\end{tabular}

Source: Own processing of data from finstat.sk 
Transit Company, Waste Removal and Disposal (Bratislava), Prešov Transit Company, Hospital of Snina, LLC, and Žilina Transit Company.

The distribution of enterprises according to their activity is presented in Table 7. The largest group deals with steam supply and cold air distribution (13.58\%). It is followed by real estate management companies that operate based on fees and contracts (9.26\%) along with forestry companies (9.26\%). Among the multiple groups of enterprises we can also include enterprises whose activity is the collection of non-hazardous waste (8.33\%) as well as enterprises engaged in the rental and operation of their own or leased real estate (8.02\%).

The subject of interest was also the management of the identified companies through which the cities conduct business. Profit or loss of these companies for the period 2012-2017 is shown in Table 8. During the period under review, the vast majority of companies managed a profit (from 205 in 2012 to 194 in 2017). In 2012, profits ranged from $44 €$ to $1,580,852 €$. The profit of $1,580,852 €$ was achieved by FCC Trnava, LLC, the owner of which is the city of Trnava. The company is engaged in collecting non-hazardous waste and generated sales of $7,317,799 €$ in that year. At the end of the reporting period, in 2017, profits ranged from $119 €$ to $821,220 €$. The company with the highest profit was Bytkomfort, LLC, in which the city of Nové Zámky has the $51 \%$ share in the registered basic capital. Its business is the supply of steam and cold air distribution.

When examining the amount of revenue, individual companies with capital share of cities were divided into five groups (Table 9). In each year, the largest group is a group of companies with sales over 1,000,000 $€$. In 2012, there were 83 companies and in the last year, in 2017, there were 79 companies. The average amount of sales in 2012 reached

Table 7 Business companies with capital share of cities by their field of activity as of December 31, 2018

\begin{tabular}{|l||c|c|}
\hline Field of activity - SK NACE & Number & $\%$ \\
\hline \hline $\mathbf{3 5 3 0 0}$ Steam supply and cold air distribution & 44 & 13.58 \\
\hline $\mathbf{6 8 3 2 0}$ Real estate management companies based on fees and contracts & 30 & 9.26 \\
\hline $\mathbf{0 2 1 0 0}$ Forestry & 30 & 9.26 \\
\hline $\mathbf{3 8 1 1 0}$ Collection of non-hazardous waste & 27 & 8.33 \\
\hline $\mathbf{6 8 2 0 0}$ Rental and operation of own or leased real estate & 26 & 8.02 \\
\hline $\mathbf{3 8 2 1 0}$ Processing and disposal of non-hazardous waste & 22 & 6.80 \\
\hline $\mathbf{9 3 1 2 0}$ Sports club activities & 16 & 4.94 \\
\hline $\mathbf{9 3 1 1 0}$ Operation of sports facilities & 15 & 4.63 \\
\hline $\mathbf{6 0 2 0 0}$ Television broadcasting and television subscription programs & 14 & 4.32 \\
\hline $\mathbf{8 1 2 9 0}$ Other cleaning activities & 12 & 3.7 \\
\hline $\mathbf{8 1 3 0 0}$ Landscaping activities & 7 & 2.16 \\
\hline $\mathbf{5 9 1 1 0}$ Production of films, videos and television programs & 5 & 1.54 \\
\hline Other & 76 & 23.46 \\
\hline Total & 324 & 100.00 \\
\hline
\end{tabular}

Source: Own processing of data from finstat.sk

Table 8 Business companies with capital share of cities by economic result

\begin{tabular}{|l||c|c|c|c|c|c|}
\hline Economic result & $\mathbf{2 0 1 2}$ & $\mathbf{2 0 1 3}$ & $\mathbf{2 0 1 4}$ & $\mathbf{2 0 1 5}$ & $\mathbf{2 0 1 6}$ & $\mathbf{2 0 1 7}$ \\
\hline \hline Profit & 205 & 231 & 210 & 229 & 228 & 194 \\
\hline Loss & 51 & 62 & 73 & 54 & 49 & 44 \\
\hline
\end{tabular}

Source: Own processing of data from finstat.sk

Table 9 Business companies with capital share of cities by revenue

\begin{tabular}{|c|c|c|c|c|c|c|}
\hline Revenues & 2012 & 2013 & 2014 & 2015 & 2016 & 2017 \\
\hline up to $50000 €$ & 32 & 31 & 28 & 32 & 32 & 25 \\
\hline $50000 €$ to $100000 €$ & 16 & 20 & 21 & 19 & 18 & 20 \\
\hline $100000 €$ to $500000 €$ & 65 & 74 & 75 & 74 & 74 & 67 \\
\hline $500000 €$ to $1000000 €$ & 49 & 57 & 61 & 60 & 51 & 41 \\
\hline over $1000000 €$ & 83 & 89 & 84 & 84 & 91 & 79 \\
\hline
\end{tabular}

Source: Own processing of data from finstat.sk 
Table 10 Business companies with capital share of cities by asset value

\begin{tabular}{|c|c|c|c|c|c|c|}
\hline Asset value & 2012 & 2013 & 2014 & 2015 & 2016 & 2017 \\
\hline up to $100000 €$ & 54 & 81 & 67 & 64 & 86 & 7 \\
\hline $100000 €$ to $500000 €$ & 40 & 56 & 60 & 56 & 61 & 7 \\
\hline $500000 €$ to $1000000 €$ & 21 & 31 & 36 & 36 & 34 & 6 \\
\hline $1000000 €$ to $5000000 €$ & 61 & 87 & 80 & 83 & 75 & 7 \\
\hline over $5000000 €$ & 31 & 38 & 40 & 39 & 52 & 174 \\
\hline
\end{tabular}

Source: Own processing of data from finstat.sk

$1,274,159.74 €$, and in 2017 it was less by $10.04 \%$, that is $1,146,237.64 €$. Approximately $10 \%$ of businesses generated sales of up to $50,000 €$ in the period under review.

The object of interest was also the analysis of the development of the value of the assets of the companies in question. From this point of view, five groups of companies have been identified and presented in Table 10. In the period under review, we can observe a gradual increase in the value of the assets of enterprises with capital share of cities. While in 2012 only 31 companies belonged to the group with a value of over 5,000,000 $€$, in the last year of 2017 it was 174 companies. An important positive effect of doing business by local self-governments through companies is to increase the value of their assets.

\section{Conclusion}

Public business can be found at all levels of governance within public administration, at supranational, federal, national, regional and local levels. The reasons why public enterprises in the world have been created vary depending on the local context.

In the paper, we focused on public enterprise, specifically on businesses with ownership of cities and on the use of self-governing assets for business purposes in Slovakia. As mentioned above, the use of public or selfgoverning assets for business purposes is realized in the Slovak Republic in three basic forms (business in the form of trading companies, through allowance organizations and doing business in municipality's own name under the Trade Licensing Act). However, what particular form of business to choose is always an individual decision of a given local self-government and this decision is also determined by the way of management and controlling the business activities. In practice, we often encounter entrepreneurship of local self-government through business companies.

Cities in the Slovak Republic have long-term business experience through business companies, which is confirmed by the fact that more than $58 \%$ of the identified enterprises were established before the year 2002. In terms of share of ownership, it is predominantly a company with $100 \%$ ownership share (65.74\%). Up to $93.21 \%$ of all businesses were limited liability companies. The basic capital was mostly $50,000 €$. $51.23 \%$ of enterprises employ fewer than 10 employees, so they are so-called micro-enterprises and only 5 enterprises qualify as large enterprises. The business activities of the companies under investigation are various; according to the SK NACE classification, the largest group of companies (13.58\%) is dedicated to steam and cold air distribution. In terms of economic results, in most of the monitored years, the vast majority of companies managed to be profitable. The research results confirm that an important effect of entrepreneurial activity of local self-governments is to increase the value of their assets.

\section{Acknowledgments}

This paper was supported by the project KEGA no. 024SPU4/2017 "Creation of modern textbooks in Slovak and English language for new study programs".

\section{References}

ARAPIS, T. 2013. Enterprise fund transfers and their impact on governmental spending and revenue patterns of Georgia municipalities. In Journal of Public Budgeting, Accounting \& Financial Management, vol. 25, 2013, no. 3, pp. 446-473.

BENČO, J. 2006. Ekonomika a manažment verejnej správy. Trenčín : Trenčianska univerzita Alexandra Dubčeka, 2006, 319 pp. ISBN 80-8075-119-6.

BEL, G. - DIJKGRAAF, E. - FAGEDA, X. - GRADUS, R. H. J. M. 2010. Similar Problems, Different Solutions: Comparing Refuse Collection in the Netherlands and Spain. In Public Administration, vol. 88, 2010, no. 2, pp. 479-495. DOI 10.1111/padm.2010.88.

BRUTON, G.D. - PENG, M.W. - AHLSTROM, D. - STAN, S. - XU, K. 2015. State-owned enterprises around the world as hybrid organizations. In The Academy of Management Perspectives, vol. 29, 2015, no. 1, pp. 92-114. DOI 10.5465/amp.2013.0069.

GARRONE, P. - GRILLI, L. - ROUSSEAU, X. 2010. Management Discretion and Political Interference in Municipal Enterprises. Evidence from Italian Utilities. In Local Government Studies, vol. 39, 2010, no. 4, pp. 1-32. DOI 10.2139/ssrn.1610124.

HAJŠOVÁ, M. - KÚTIK J. 2009. Ekonomika a manažment samosprávy. Trenčín : Trenčianska univerzita Alexandra Dubčeka, 2009, 138 pp. ISBN 978-88- 0907-543-10.

PAPCUNOVÁ, V. - BALÁŽOVÁ, E. 2006. Majetok obcí. Nitra : Slovenská akadémia pol'nohospodárskych vied. ISBN 80-89162-19-3.

Slovak Republic Act No. 369/1990 Coll. on Municipalities.

Slovak Republic Act No. 513/1991 Coll. Commercial Code.

TÓTH, P. - MICHLOVÁ, R. - TRHLÍNOVÁ, Z. - VOCHOZKOVÁ, J. - HESOUN, R. 2014. Ekonomické aktivity obcí a měst. Plzeň : Vydavatelstí a nakladatelství Aleš Čeňek s.r.o., 2014, 125 pp. ISBN 978-80-7380-491-6.

VOORN, B. - VAN GENUGTEN, M.L. - VAN THIEL, S. 2017. The efficiency and effectiveness of municipally owned corporations: a systematic review. In Local Government Studies. DOI 10.1080/03003930.2017.1319360. 